\title{
Evaluation of Alpha 1-Antitrypsin for the Early Diagnosis of Colorectal Cancer
}

\author{
Hajar Jaberie ${ }^{1,2} \cdot$ Seyed Vahid Hosseini ${ }^{3} \cdot$ Fakhraddin Naghibalhossaini $^{1,4}$ (I)
}

Received: 5 February 2019 / Accepted: 29 May 2019/Published online: 10 June 2019

(C) Arányi Lajos Foundation 2019

\begin{abstract}
Previous proteomic studies have identified alpha 1-antitrypsin (A1AT) as a potential serum biomarker for colorectal cancer (CRC). In this case-control study, we evaluated plasma A1AT concentration and activity as a biomarker for the early diagnosis of colorectal cancer in a group of 113 sporadic CRC patients. We also analyzed A1AT gene promoter methylation, and genotypes in this group of CRC patients. The plasma A1AT and CEA concentrations were measured using the nephelometric and ELISA methods, respectively. A1AT activity was determined by Trypsin Inhibitor Capacity assay. The genomic DNA from blood samples were subjected to $\mathrm{Z}$ and $\mathrm{S}$ genotype analysis using PCR-RFLP method and the gene promoter methylation in tumors and their adjacent normal tissues was determined by methylation specific-PCR assay. The plasma levels of A1AT and CEA in patients (median, $2.3 \mathrm{~g} / \mathrm{L}$ and $5.96 \mathrm{ng} / \mathrm{ml}$, respectively) were significantly higher than those in healthy controls (medians, $1.43 \mathrm{~g} / \mathrm{L}$ and $2.57 \mathrm{ng} / \mathrm{ml}$, respectively) $(p=0.0001)$. The plasma A1AT activity and concentrations were positively correlated with the tumor stage and well-discriminated between early and advanced stages. The A1AT activity in plasma was the most useful marker for CRC diagnosis (median $4.8 \mathrm{mmol} / \mathrm{min} / \mathrm{ml}$ in cases vs $1.91 \mathrm{mmol} / \mathrm{min} / \mathrm{ml}$ in controls, $p=0.0001$ ). No deficient $Z$ or S alleles of A1AT was observed in patients' genotype and the gene promoter tends to be more methylated in normal mucosa than in tumor tissues. We conclude that plasma A1AT activity has better sensitivity and specificity than CEA measurement for the early detection of CRC. Promoter demethylation might play a role in increasing plasma A1AT levels in CRC patients.
\end{abstract}

Keywords Alpha 1-antitrypsin $\cdot$ Colorectal Cancer $\cdot$ CEA $\cdot$ Promoter methylation

\section{Background}

Colorectal cancer (CRC) is one of the leading causes of cancerrelated mortality worldwide [1] and its incidence in Iran has also dramatically increased during the last few decades [2]. Serum-based sensitive biomarker for the early detection of $\mathrm{CRC}$ is essential for effective treatments and disease-free

Fakhraddin Naghibalhossaini

fakhraddin.naghibalhossaini@mail.mcgill.ca

1 Department of Biochemistry, School of Medicine, Shiraz University of Medical Sciences, Zand Street, Shiraz 7134845794, Iran

2 Present address: Department of Biochemistry, School of Medicine, Bushehr University of Medical Sciences, Bushehr, Iran

3 Colorectal Research Center, Shiraz University of Medical Sciences, Shiraz, Iran

4 Autoimmune Research Center, Shiraz University of Medical Sciences, Shiraz, Iran survival of patients. Measurement of carcinoembryonic antigen (CEA) level in the serum of CRC patients is widely used for monitoring disease progression and recurrence after treatment [3]. It has been suggested that the preoperative serum CEA level might be also a useful indicator for CRC-liver metastasis $[4,5]$. However, CEA lack sufficient specificity and sensitivity to be considered for specific diagnosis or early malignancy detection [6]. Therefore, the identification of new noninvasive serum-based biomarkers for the accurate detection of the early stage CRC is an open field of research.

Previous studies have suggested associations between inflammatory process and development of several types of cancer $[7,8]$. The association between chronic inflammation and $\mathrm{CRC}$ risk is controversial. Some studies have reported positive associations between serum inflammatory markers, $\mathrm{C}$-reactive protein (CRP) and haptoglobin and CRC risk [9, 10]. Alpha1-antitrypsin (A1AT), a major serum serine proteinase inhibitor, is highly expressed during inflammation predominantly by liver hepatocytes. In addition to liver hepatocytes, A1AT gene is also expressed in human blood monocytes and 
intestinal epithelium, and colonic tumor cell lines [11]. A1AT as an acute phase protein, primarily protects the connective tissue of lungs against serine proteases including neutrophil elastase [12]. A1AT also demonstrates anti-inflammatory activity by inhibiting inflammatory responses and cytokine production by phagocytic cells, such as macrophages, monocytes, and neutrophils [13, 14].

Several clinical studies have indicated increased serum A1AT levels in various types of malignancy, such as lung, liver, bladder, breast, prostate, pancreas, and esophageal cancer [15-19]. A1AT has been also suggested as a potential diagnostic biomarker for the early-stage detection of gastrointestinal inflammation [20]. The relationship between serum A1AT levels and CRC remains controversial. Few studies to date have investigated the association between A1AT activity and the risk of CRC [21-24]. Both high and low concentrations of serum A1AT levels have been proposed to be associated with CRC incidence $[22,23,25,26]$. A positive correlation between serum levels of A1AT and the clinical stage of CRC progression has been also reported $[21,22,26]$. Several polymorphisms of the A1AT gene (SERPINA1) are associated with the low level of plasma A1AT protein and the most common deficiency-associated A1AT genotypes are protease inhibitor Z (PiZ) and protease inhibitor S (PiS) variants [27]. Deficient $Z$ and $S$ alleles of A1AT have been reported to be associated with an increased risk for developing certain cancers including hepatocellular carcinoma, lung, and bladder cancer $[16,17,28]$.

DNA methylation is a major epigenetic mechanism involved in the regulation of gene transcription. Previous studies have suggested that the promoter DNA methylation might play a role in the regulation of A1AT gene expression [29, 30]. The present case-control study was performed to investigate the association between A1AT activity, A1AT genotype variation, A1AT gene promoter methylation, and CRC susceptibility in patients from Fars, a southern province of Iran. The diagnostic value of preoperative serum A1AT was also assessed and compared with CEA, the most widely used marker in CRC patients.

\section{Methods}

\section{Blood and Tissue Samples}

A total of 113 preoperative blood samples and 86 surgical resected CRC tumor tissues were obtained from the university-affiliated Shahid Faghihi hospital in Shiraz, Southern Iran. Tumor samples were snap frozen immediately after surgical resection and stored at $-80^{\circ} \mathrm{C}$.

Blood samples were also collected from 50 age and sexmatched healthy blood donors having no history of cancerous or genetic diseases as control subjects. Blood and plasma samples were stored at $-80{ }^{\circ} \mathrm{C}$ until analysis. The study protocol was approved by the university ethical committee (Approval Number: 92-15,865/ 03-08-2013) and signed informed consent was obtained from study subjects.

\section{Measurement of Plasma A1AT Concentration, A1AT Activity and CEA Levels}

The plasma A1AT level was measured by nephelometry using commercially available antibodies (MININEPH, Birmingham, UK), with an Array ${ }^{\mathrm{TM}}$ Protein System autoanalyzer (Beckman Instruments, Brea, California, USA). A1AT activity was determined by Trypsin Inhibitor Capacity (TIC) assay using the chromogenic substrate $\alpha$-N-benzoyl DL-argenine-pnitroanilide (BAPNA, Sigma) as described previously [31]. The concentration of CEA in plasma samples was determined using a commercial CEA EIA kit (CanAg, Sweden), with a microplate reader (Mikura Optica LTD, UK) following the manufacturer's instructions.

\section{DNA Extraction and Genotyping}

Genomic DNA was extracted from peripheral blood leucocytes and tissue samples using the standard phenol-chloroform protocol. Two single nucleotide polymorphisms (SNPs) of serpinAl gene, $S$ variant (rs 17580) and Z variant (rs28929474), associated with A1AT deficiencies were genotyped by PCR followed by restriction fragment length polymorphism (RFLP) analysis. Briefly, PCR reaction was carried out in a $50 \mu \mathrm{L}$ reaction mixture containing $0.1 \mathrm{mM}$ dNTPs, $1.5 \mathrm{mM} \mathrm{MgCl}_{2}, 10 \mathrm{pM}$ of each specific oligonucleotide primers (Table 1), $150 \mathrm{ng}$ of genomic DNA, and $0.25 \mathrm{U}$ of Taq DNA polymerase (MBI Fermentas, Vilnius, Lithuania). Amplification was carried out with an initial denaturation at $94{ }^{\circ} \mathrm{C}$ for $5 \mathrm{~min}$, and then 35 cycles of $94{ }^{\circ} \mathrm{C}$ denaturation, $57{ }^{\circ} \mathrm{C}$ annealing, and $72{ }^{\circ} \mathrm{C}$ extension, each for $45 \mathrm{~s}$, followed by a final extension at $72^{\circ} \mathrm{C}$ for $10 \mathrm{~min}$, in a PCR thermal cycler (Eppendorf, Germany). For RFLP analysis, $10 \mu \mathrm{l}$ of PCR products were digested with $10 \mathrm{U}$ Taq I restriction enzyme (MBI Fermentas, Vilnius, Lithuania) at $65^{\circ} \mathrm{C}$ for $2 \mathrm{~h}$, and digestion products were analyzed on $2 \%(w / v)$ agarose gel.

\section{Bisulfite Treatment of DNA and Methylation-Specific PCR (MS-PCR)}

The status of promoter methylation of SERPINA1 gene in tumors and their adjacent normal tissues was determined by MS-PCR. Bisulfite modification of each DNA sample was performed as previously described [32] and bisulfite-treated DNA was PCR-amplified using primers (Table 1) designed for specific amplification of both methylated and unmethylated promoter region of the gene. Amplification was performed by an initial denaturation at $95^{\circ} \mathrm{C}$ for $5 \mathrm{~min}$, and then 40 cycles of denaturation at $95^{\circ} \mathrm{C}$ for $45 \mathrm{~s}$, primer annealing at $60^{\circ} \mathrm{C}$ for 
Table 1 Primers' sequence and the annealing temperature used for A1AT genotyping and MSPCR

\begin{tabular}{llc}
\hline & Sequence & Product size (bp) \\
\hline $\begin{array}{l}\text { Genotyping } \\
\text { S allele }\end{array}$ & F: 5'-TGAGGGGAAACTACAGCACCT -3' \\
& R: 5'-AGGTGTGGGCAGCTTCTTGGTCA-3' & \\
Z allele & F: 5'-ATAAGGCTGTGCTGACCATCGTC-3' & 121 \\
& R: 5'-TTGGGTGGGATT CACCACTTTTC-3' & \\
MS-PCR & F: 5'-TAGGTAAAGTGTTTGGGTAGTG-3' \\
SERPINA1 (U) & R: 5'-AACAAAACCCTATCCTCATCCA-3' & 171 \\
SERPINA1 (M) & F: 5'-AGGTAAAGCGTTCGGGTAGCG-3' & 169 \\
& R: 5'-ACAAAACCCTATCCTCGTCCG-3' & \\
\hline
\end{tabular}

$F$ Forward, $R$ Reverse, $U$ Unmethylated, $M$ Methylated
$30 \mathrm{~s}$, extension at $72{ }^{\circ} \mathrm{C}$ for $30 \mathrm{~s}$, followed by a final extension at $72{ }^{\circ} \mathrm{C}$ for $10 \mathrm{~min}$. In every sodium bisulfite modification reaction, DNA from human liver HepG2 cell line and human methylated DNA standard (ZYMO Research, Freiburg, Germany) were used as unmethylated (negative) and methylated (positive) controls, respectively. MS-PCR reaction products were separated by electrophoresis on $2 \%$ agarose gel.

\section{Statistical Analysis}

Statistical analyses were performed using SPSS Software version 17 (SPSS, Inc., Chicago), MedCalc version 14 (MedCalc Software, Ostend, Belgium), and GraphPad Prism version 5 (GraphPad Software Inc., San Diego, CA, USA). Quantitative variables are expressed as medians or means and standard error of mean (mean $\pm \mathrm{SEM}$ ). Parameters were compared between cancer cases and healthy controls by using the Student's $t$ test. One-way analysis of variance ANOVA and multiple comparisons (post-hoc) pairwise Tukey's test were applied to evaluate the differences of some markers according to the stage and grade of tumors. Correlation coefficient (r) was calculated by Pearson or Spearman correlation test. Area under receiver operating characteristic (ROC) curve was used to compare serum markers diagnostic accuracy and to verify whether they could be used to discriminate between CRC cases and controls. Associations between methylation and clinical, biological features of tumors were evaluated using Chi square or Fisher's exact test, as appropriate. A $p$ value of $\leq 0.05$ was considered to be statistically significant.

\section{Results}

The study group consisted of 113 patients including 59 (52.2\%) males with an average age of $60.98 \pm 2.05$ years and $54(47.8 \%)$ females with an average age of $54.35 \pm$ 1.8 years. The control group consisted of 50 healthy individuals including 28 (56\%) of males with an average age of
$59.03 \pm 1.47$ years and $22(44 \%)$ of females with an average age of $61.04 \pm 2.01$ years. Ninety-six patients $(85 \%)$ had tumors in the left side of colon, 5 patients $(4.42 \%)$ had malignancies in the right side colon, and $9(8 \%)$ had total colectomy. In this group of patients, $72(63.7 \%)$ of tumors were welldifferentiated, $25(22.1 \%)$ were moderately differentiated, 4 $(3.5 \%)$ were poorly differentiated, and $3(2.7 \%)$ were mucinous. The tumors were classified as stage I in $31(27.4 \%)$, stage II in $36(31.9 \%)$, stage III in $26(23.0 \%)$, and stage IV in 8 $(7.1 \%)$ of patients (Table 2$)$.

\section{Measurement of A1AT Activity and Concentrations of CEA and A1AT in Plasma}

Analysis of plasma data revealed significant differences between cases and controls in the levels of CEA and A1AT concentrations as well as plasma A1AT activity (Table 2). The range of CEA concentrations were $0.42-164.25 \mathrm{ng} / \mathrm{ml}$ (median $5.96 \mathrm{ng} / \mathrm{ml}$ ) in the patients with CRC compared to $0.26-10.8 \mathrm{ng} / \mathrm{ml}$ (median $2.57 \mathrm{ng} / \mathrm{ml}$ ) in the healthy controls $(p<0.0001)$. The range of A1AT levels in plasma was 1.05$4.24 \mathrm{~g} / \mathrm{L}$ (median $2.3 \mathrm{~g} / \mathrm{L}$ ) in patients and $1.01-2.13 \mathrm{~g} / \mathrm{L}$ (median $1.43 \mathrm{~g} / \mathrm{L})$ in controls $(p=0.0001)$. The range of plasma A1AT activity from cancer patients and control group were $1.36-7.82 \mu \mathrm{mol} / \mathrm{min} / \mathrm{ml}$ (median 4.8 ) and $1.15-2.91 \mu \mathrm{mol} /$ $\mathrm{min} / \mathrm{ml}$ (median 1.91), respectively $(\mathrm{p}=0.0001)$. Age and gender-stratified analyses reveled that all sex and age $(<60$ and $\geq 60$ ) subgroups of patients had higher CEA and A1AT values than their respective controls (Table 2). There were, however, no significant differences in the mean values of plasma A1AT activity and CEA and A1AT concentrations in either cases or controls stratified by sex or age.

\section{Relationship Between Plasma Biomarkers and Clinicopathological Features of CRC Patients}

The correlation of mean values of the parameters measured in patient's sera to the clinicopathological features of the disease 
Table 2 Plasma A1AT and CEA concentration and A1AT activity level according to some clinical features of cases and controls

\begin{tabular}{|c|c|c|c|c|c|c|c|c|c|c|c|c|}
\hline Group & $\begin{array}{l}\text { A1AT } \\
\text { median } \\
(\mathrm{g} / \mathrm{L})\end{array}$ & $\begin{array}{l}\text { A1AT } \\
\text { Mean } \pm \text { SEM } \\
(\mathrm{g} / \mathrm{L})\end{array}$ & ${ }^{\mathrm{a} P}$ & ${ }^{b} \mathrm{P}$ & $\begin{array}{l}\text { A1AT activity } \\
\text { Median } \\
(\mu \mathrm{mol} / \mathrm{min} / \mathrm{ml})\end{array}$ & $\begin{array}{l}\text { A1AT activity } \\
\text { Mean } \pm \text { SEM } \\
(\mu \mathrm{mol} / \mathrm{min} / \mathrm{ml})\end{array}$ & ${ }^{\mathrm{a}} \mathrm{P}$ & ${ }^{\mathrm{b}} \mathrm{P}$ & $\begin{array}{l}\text { CEA } \\
\text { Median } \\
(\mathrm{ng} / \mathrm{ml})\end{array}$ & $\begin{array}{l}\text { CEA } \\
\text { Mean } \pm \text { SEM } \\
(\mathrm{ng} / \mathrm{ml})\end{array}$ & ${ }^{\mathrm{a}} \mathrm{P}$ & ${ }^{\mathrm{b}} \mathrm{P}$ \\
\hline \multicolumn{13}{|l|}{ Case (n) } \\
\hline Total (113) & 2.3 & $2.34 \pm 0.06$ & 0.0001 & & 4.8 & $4.77 \pm 0.15$ & 0.0001 & & 5.96 & $15.39 \pm 2.7$ & 0.0001 & \\
\hline \multicolumn{13}{|l|}{ Age } \\
\hline$<60(62)$ & 2.36 & $2.4 \pm 0.09$ & 0.0001 & \multirow[t]{2}{*}{ NS } & 4.86 & $4.83 \pm 0.21$ & 0.0001 & \multirow[t]{2}{*}{ NS } & 5.7 & $17.58 \pm 4.2$ & 0.001 & $\mathrm{~N}$ \\
\hline$\geq 60(48)$ & 2.23 & $2.2 \pm 0.09$ & 0.0001 & & 4.75 & $4.62 \pm 0.21$ & 0.0001 & & 6.5 & $13.38 \pm 3.66$ & 0.007 & \\
\hline \multicolumn{13}{|l|}{ Sex } \\
\hline Female (54) & 2.4 & $2.36 \pm 0.09$ & 0.0001 & \multirow[t]{2}{*}{ NS } & 4.6 & $4.6 \pm 0.24$ & 0.0001 & \multirow[t]{2}{*}{ NS } & 5.8 & $15.29 \pm 4.21$ & 0.009 & $\mathrm{~N}$ \\
\hline Male (59) & 2.26 & $2.32 \pm 0.08$ & 0.0001 & & 5.07 & $4.8 \pm 0.18$ & 0.0001 & & 6.01 & $15.48 \pm 3.7$ & 0.001 & \\
\hline \multicolumn{13}{|l|}{ Tumor size } \\
\hline$<5 \mathrm{~cm}(70)$ & 2.15 & $2.1 \pm 0.07$ & & \multirow[t]{3}{*}{0.0001} & 4.51 & $4.4 \pm 0.19$ & & \multirow[t]{3}{*}{0.01} & 5.88 & $11.77 \pm 2.48$ & & $\mathrm{~N}$ \\
\hline$\geq 5 \mathrm{~cm} \mathrm{(32)}$ & 2.73 & $2.6 \pm 0.12$ & & & 5.26 & $5.2 \pm 0.26$ & & & 7.27 & $18.88 \pm 6.14$ & & \\
\hline \multirow{2}{*}{\multicolumn{10}{|c|}{$\begin{array}{l}\text { Missing (11) } \\
\text { Tumor site }\end{array}$}} & & & \\
\hline & & & & & & & & & & & & \\
\hline Right side (5) & 2.56 & $2.4 \pm 0.34$ & & \multirow[t]{4}{*}{ NS } & 3.63 & $4.96 \pm 0.82$ & & \multirow[t]{4}{*}{ NS } & 3.38 & $31.03 \pm 22.22$ & & $\mathrm{~N}$ \\
\hline Left side (96) & 2.31 & $2.3 \pm 0.06$ & & & 4.78 & $4.77 \pm 0.16$ & & & 6.57 & $13.61 \pm 2.54$ & & \\
\hline Total Colectomy (9) & 2.45 & $2.48 \pm 0.25$ & & & 4.8 & $4.49 \pm 0.65$ & & & 2.3 & $30.02 \pm 18.77$ & & \\
\hline Missing (3) & & & & & & & & & & & & \\
\hline \multicolumn{13}{|l|}{ Control (n) } \\
\hline Total (50) & 1.43 & $1.4 \pm 0.03$ & & & 1.91 & $2 \pm 0.05$ & & & 2.57 & $3.22 \pm 0.36$ & & \\
\hline \multicolumn{13}{|l|}{ Age } \\
\hline$<60(30)$ & 1.48 & $1.5 \pm 0.04$ & & \multirow[t]{2}{*}{ NS } & 1.93 & $2.02 \pm 0.08$ & & \multirow[t]{2}{*}{ NS } & 2.64 & $3.4 \pm 0.5$ & & $\mathrm{~N}$ \\
\hline$\geq 60(20)$ & 1.4 & $1.48 \pm 0.06$ & & & 1.87 & $1.98 \pm 0.08$ & & & 2.16 & $2.8 \pm 0.51$ & & \\
\hline \multicolumn{13}{|l|}{ Sex } \\
\hline Female (22) & 1.4 & $1.48 \pm 0.05$ & & \multirow[t]{2}{*}{ NS } & 1.84 & $1.94 \pm 0.09$ & & \multirow[t]{2}{*}{ NS } & 2.9 & $3.7 \pm 0.61$ & & $\mathrm{~N}$ \\
\hline Male (28) & 1.43 & $1.50 \pm 0.05$ & & & 1.93 & $2.05 \pm 0.07$ & & & 2.55 & $2.8 \pm 0.42$ & & \\
\hline
\end{tabular}

NS Not significant

${ }^{\text {a }} P$-values for case-control comparisons from the Student's $t$ test where appropriate

${ }^{\mathrm{b}} P$-values for subgroups comparison from the Student's $t$ test where appropriate

are shown in Table 2. There were no significant differences in the mean plasma CEA or A1AT concentrations and A1AT activity levels between patient groups divided based on tumor site (Table 2). In our study group, 70 patients $(68.6 \%)$ had tumors smaller than $5 \mathrm{~cm}$ and 32 patients $(31.4 \%)$ had tumors larger than $5 \mathrm{~cm}$.

The statistical analysis indicated that the mean value of A1AT concentration and A1AT activity levels were significantly higher in plasma of patients with large tumor size $(\geq 5 \mathrm{~cm})$ than those with small tumors $(<5 \mathrm{~cm})(P<0.05)$ (Table 2). The range of A1AT concentrations in CRC patients with large tumor size and small tumor size were 1.25-4.24 (median 2.73) $\mathrm{g} / \mathrm{L}$ and $1.05-3.55$ (median 2.15) $\mathrm{g} / \mathrm{L}(p=$ $0.0001)$, respectively. The range of plasma A1AT activity levels in patients with large tumor size was 1.91-7.82 (median 5.26 ) and in patients with small tumor was1.36-7.63 (median $4.5) \mu \mathrm{mol} / \mathrm{min} / \mathrm{ml}(p=0.01)$. There was no significant difference in the mean of plasma CEA concentration between tumor size subgroups.

The range of plasma CEA in stage I, II, III, and IV were 1.33-138.89 (median 5.1), 0.42-116.94 (median 5.67), 0.531.72 (median 7.72), and 1.23-164.25 (median 39.35) ng/ml, respectively. The CEA level in CRC patients at stage IV was significantly higher than those in other stages and in the control group ( $P=0.0001)$ (Fig. 1a). As shown in Fig. 1b, the mean of plasma CEA levels in patients with poorly differentiated tumor was significantly higher than those in with well and moderately differentiated tumor $(P<0.05)$. There were no significant differences in the mean A1AT concentration and A1AT activity levels between various differentiation groups. The mean serum levels of plasma A1AT activity and concentration in all stages of colorectal cancer were significantly higher than in healthy controls (Fig. 1c and d). In patients with stage I tumors the mean values of plasma A1AT concentrations and activity was significantly lower than in the remaining subgroups $(P<0.05)$. The range of A1AT concentrations determined in patients with tumor stage I, II, III, and IV were 1.05-3.55 (median 1.58), 1.22-4.24 (median 2.28), 1.15-3.48 (median 2.67), and 1.683.5 (median 2.96) g/L, respectively. The range of A1AT activity in stage I, II, III and IV were 1.40-7.30 (median 2.85), 1.36-7.82 (median 4.66), 2.77-7.43 (median 5.44), and 37.30 (median 5.99) $\mu \mathrm{mol} / \mathrm{min} / \mathrm{ml}$, respectively.

In CRC patients, A1AT concentration was positively correlated with CEA concentration $(r=0.2, p=0.03)$, but there was no significant correlation between plasma A1AT activity and CEA level $(r=0.112, p=0.23)$. The area under the ROC curve (AUC) of A1AT concentration and activity were significantly higher than AUC of CEA $(P=0.01, P<0.0001$, 
Fig. 1 Plasma CEA (a) and A1AT concentration (b) and A1AT activity (c) in the healthy controls and CRC patients according to tumor stages. $P$ value from Tukey test. *significant difference ( $p=$ $0.0001)$
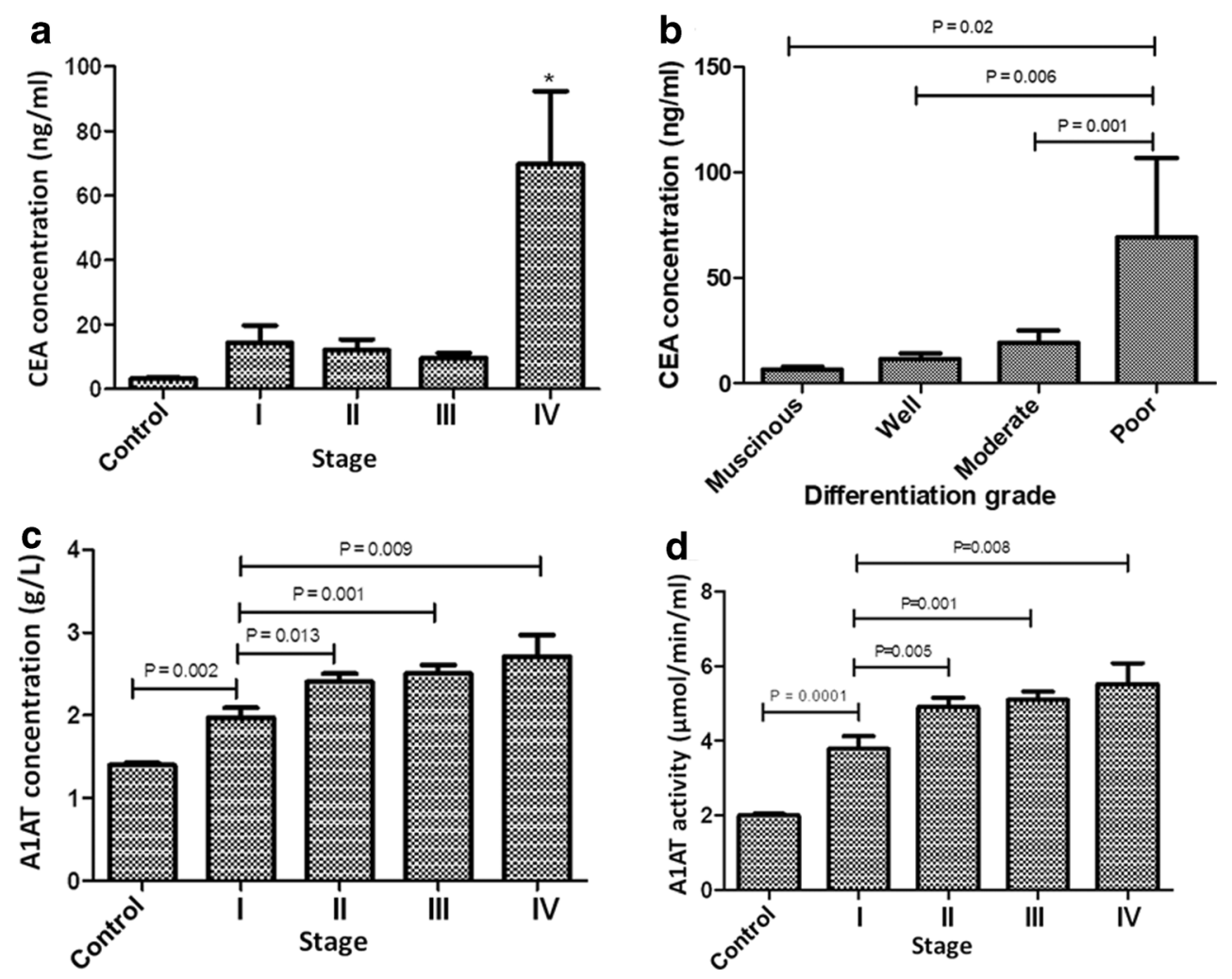

respectively) (Fig. 2a). The AUC of plasma A1AT activity was also significantly more than the AUC of A1AT concentration $(P=0.0004)$. The AUC for CEA and A1AT concentrations and A1AT activity were 0.74 (95\% CI: $0.67-0.81), 0.86$ (95\% CI: $0.80-0.91$ ), and 0.94 (95\% CI: 0.89-0.97), respectively. At a cut-off point of $3.56 \mathrm{ng} / \mathrm{ml}$ for CEA, the optimal sensitivity and specificity were $70.8 \%$ and $70 \%$, respectively for discriminating CRC patients from healthy controls (Fig. 2b). The ideal cut off value identified from the ROC curve for A1AT concentration was $1.88 \mathrm{mg} / \mathrm{L}$ with the sensitivity of $75.2 \%$ and the specificity of $90 \%$ in detecting cancer patients from healthy controls (Fig. 2c). The ideal cut-off value for plasma A1AT activity was $2.91 \mu \mathrm{mol} / \mathrm{min} / \mathrm{ml}$ with the sensitivity of $84.1 \%$ and the specificity of $100 \%$ for discriminating cancer patients from healthy controls (Fig. 2d).

\section{SERPINA1 Genotype and Promoter DNA Methylation}

DNA samples from CRC patients were analyzed for $Z$ or $S$ alleles in SERPINA1 gene by PCR-RFLP method, as described in the "Methods" section. Taq I digestion of the PCR-amplified product using either $Z$ or $S$ primers results in two fragments for the normal $\mathrm{M}$ allele. The presence of mutant $\mathrm{Z}$ or $\mathrm{S}$ allele abolishes the Taq I restriction site within the amplified fragments. Agarose gel electrophoresis of PCRRFLP products (Fig. 3a and b) produced no detectable $S$ or $Z$ mutation in all 113 samples studied. The results indicated that normal homozygous MM genotype of SERPINA1 gene is present in this group of CRC patients.

We also investigated the promoter methylation status of SERPINA1 gene in CRC tumors and their adjacent normal tissues in a subgroup of 86 patients. Illustrative examples of MS-PCR results of the promoter methylation analysis are shown in Fig. 3c. Table 3 summarizes the association between SERPINA1 promoter methylation and clinicopathological characteristics of CRC patients. SERPINA1 promoter was fully methylated in $7(8.1 \%)$ and partially methylated (hemimethylated) in $79(91.9 \%)$ of tumors. The frequency of fully methylated SERPINA1 promoter in normal colorectal mucosa was significantly higher than that in tumor tissues (53.2\% versus $8.1 \%, p<0.0001)$. There was also significant association between differentiation state of tumors and SERPINA1 gene methylation. Six out of 7 tumors $(85.7 \%)$ with fully-methylated SERPINA1 gene were welldifferentiated $(p=0.02)$. There was no significant association between SERPINA1 gene methylation and other clinicalpathological features of CRC patients (Table 3 ).

\section{Discussion}

The relationship between A1AT and CRC has been controversial, both higher and lower blood levels have been reported as compared to healthy controls $[20,22,26]$. The results of 
Fig. 2 The sensitivity and specificity analysis of plasma A1AT and CEA for detection of CRC. a ROC curves comparing A1AT and CEA concentration and A1AT activity in plasma of CRC patients. The area under ROC curves for A1AT activity and concentration and CEA level were $0.94,0.74$, and 0.86 , respectively. $\mathbf{b}$, $\mathbf{c}$, and $\mathbf{d}$ indicate the cut-off value with the highest accuracy (minimal false negative and false positive) for each marker

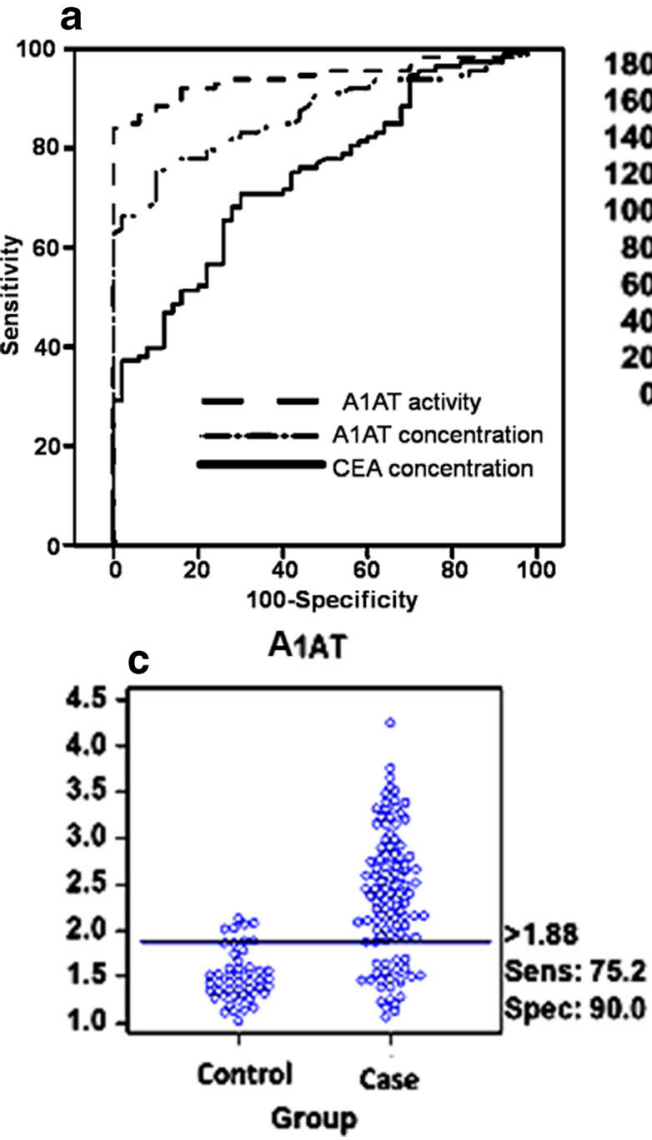

b CEA

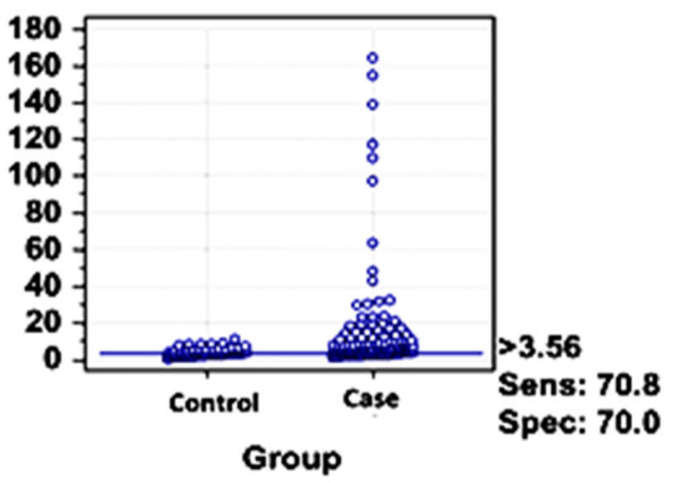

d A1AT activity

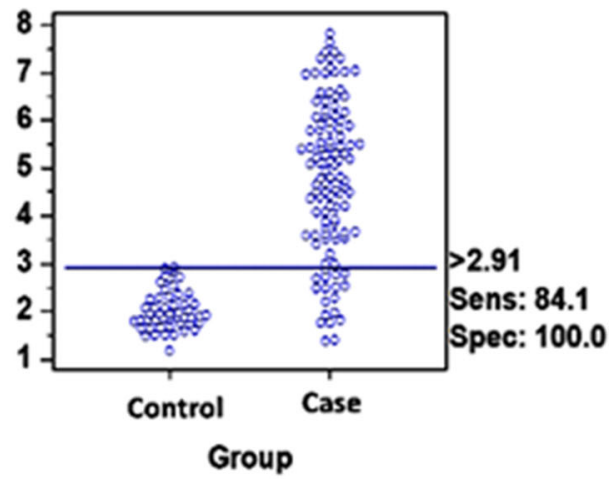

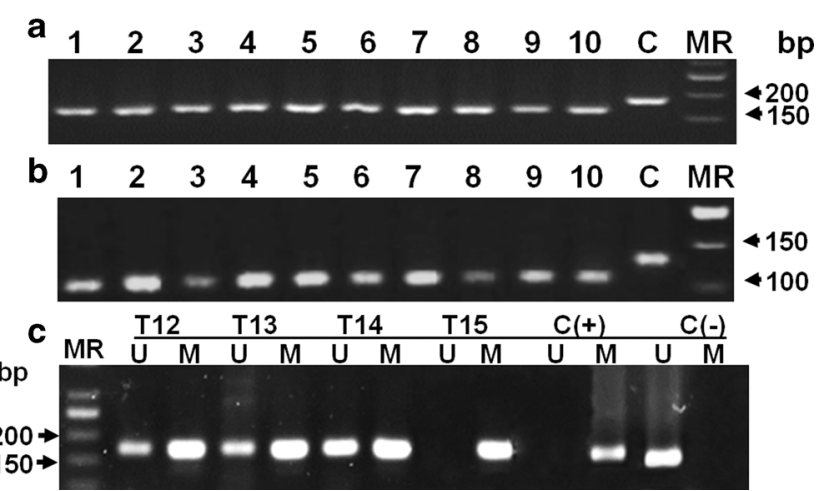

Fig. 3 Genotype and promoter DNA methylation analysis of Serpin Al gene in CRC patients. a PCR-RFLP assay for the detection of $Z$ mutation of A1AT gene in DNA isolated from patients' blood. Taq I enzyme digestion of the 179-bp PCR amplified M allele yields two fragments of 157 and 22 bp (lanes 1-10), whereas the $Z$ allele results in an undigested fragment. Lane C (control) is a 179-bP undigested PCR product. b PCRRFLP assay for the detection of $\mathrm{S}$ allele. Taq I digestion of the 121-bp PCR-amplified M allele yields two fragments of 100 and 21 bp (lanes 110 ), whereas the $S$ allele results in an undigested fragment. Lane $C$ (control) is a 121-bp undigested PCR product. $\mathbf{c}$ Representative examples of MS-PCR reactions for promoter methylation analysis of Serpin A1 gene in primary CRC tumors. U: Unmethylated gene; M: Methylated gene; C (+): Methylated control; C (-): Umethylated control; MR: 50 bp DNA size marke present study corroborate previously published studies showing a significantly higher concentration of serum A1AT in CRC patients than in healthy controls $[22,26]$. The mean plasma values of A1AT and CEA concentrations and A1AT activity in CRC patients were significantly higher than those of the healthy blood donors $(p=0.0001$, Table 2$)$. Moreover, our results suggest a better sensitivity of plasma A1AT than CEA for early detection of CRC. A detailed analysis revealed that the concentration and activity of A1AT in plasma progressively increased with increasing severity of the colorectal cancer. Moreover, the mean A1AT concentration and activity in patients with all stages and grades of tumors were also higher than those in controls $(p<0.01)$ (Fig. 1). But only patients with stage IV of CRC had significantly higher plasma CEA than normal controls and the mean CEA levels only in the subgroup of patients with poorly differentiated tumors was significantly different from other differentiation subgroups (Fig. 1b). In agreement with a previous report [22], we also observed a higher serum A1AT concentrations in cases with high stage (III and IV) than those with early stage tumors (I and II).

CEA is the most widely used tumor marker especially for monitoring CRC treatment. But, because of lack of sufficient sensitivity and specificity it could not be used for screening or 
Table 3 SERPINA1 gene promoter methylation and clinicopathological features of CRC patients

\begin{tabular}{lllll}
\hline Variables & $\mathrm{N}(\%)$ & $\mathrm{M}$ & $\mathrm{M} / \mathrm{U}$ & $\mathrm{p}$ \\
& & $\mathrm{N}(\%)$ & $\mathrm{N}(\%)$ & \\
\hline Total & 86 & $7(8.1)$ & $79(91.9)$ & \\
Age & & & & \\
$<60$ & $30(34.9)$ & $2(28.6)$ & $34(43)$ & $0.69^{\mathrm{a}}$ \\
$>60$ & $50(58.1)$ & $5(71.4)$ & $45(57)$ & \\
Sex & & & & \\
Female & $30(34.9)$ & $2(28.6)$ & $28(35.4)$ & $1.00^{\mathrm{a}}$ \\
Male & $56(65.1)$ & $5(71.4)$ & $51(64.6)$ & \\
Clinical stage & & & & \\
I & $12(14)$ & $0(0)$ & $12(15.2)$ & $0.65^{\mathrm{b}}$ \\
II & $50(58.1)$ & $5(71.4)$ & $45(57)$ & \\
III & $21(24.4)$ & $2(28.6)$ & $19(24.1)$ & \\
IV & $3(3.5)$ & $0(0)$ & $3(3.8)$ & \\
Differentiation grade & & & \\
Poor & $5(5.8)$ & $1(14.3)$ & $4(5.1)$ & $0.029^{\mathrm{b}}$ \\
Moderate & $41(47.7)$ & $0(0)$ & $41(51.9)$ & \\
Well & $40(46.5)$ & $6(85.7)$ & $34(43)$ & \\
Tumor site & & & & \\
Right side & $10(11.6)$ & $0(0)$ & $22(27.8)$ & $1.00^{\mathrm{a}}$ \\
Left side & $76(88.4)$ & $7(100)$ & $57(72.2)$ & \\
\end{tabular}

$M$ Methylated promoter, $M / U$ Hemi-methylated promoter

${ }^{a} P$-value from Fisher's exact tests

${ }^{\mathrm{b}} P$-value from Chi-Square tests

diagnosis. The ROC curve analysis indicated that plasma A1AT has a better sensitivity and specificity than CEA to discriminate CRC patients from healthy individuals. While at the optimal cut off value, plasma CEA levels had a sensitivity of $70.8 \%$ and specificity of $70 \%$ for discriminating CRC cases from controls, A1AT in plasma had a sensitivity and specificity of $75.2 \%$ and $90 \%$, respectively (Fig. 2). Nine percent of CRC cases were cigarette smokers. Since smoking has been reported to increase blood CEA level, we evaluated the possible effect of smoking on the plasma CEA levels. The difference in plasma CEA concentrations between smokers and non-smokers was not statically significant (data not shown) $(p>0.05)$.

At the optimal cut off, the predicted probability on the basis of plasma A1AT activity had $84.1 \%$ sensitivity and $100 \%$ specificity, with an AUC of 0.94 (Fig. 2d). These findings suggest that the plasma A1AT activity is a better biomarker than plasma A1AT protein for the early detection of CRC. Recent studies indicate that certain mutations in SERPINA1 gene result in A1AT proteins with an impaired anti-protease activity $[33,34]$. These variants which are secreted at normal or enhanced levels but lack antiprotease activity, are likely over-estimate the amount of functional A1AT measured in the circulation. Therefore, the measurement of the A1AT activity may be a better biomarker than A1AT protein level.

Our results are also in agreement with previous studies of the proteomic analysis of serum samples reporting that A1AT outperforms serum CEA for discriminating CRC patients from healthy individuals $[25,35]$. However, elevated blood A1AT levels are observed in other types of malignant and non-malignant diseases. Therefore, its measurement alone does not provide the required specificity for the early detection of CRC.

We also analyzed the cases for the presence of A1ATdeficient $S$ and $Z$ alleles. We did not detect any $S$ or $Z$ variants in any of 113 CRC samples studied. These results demonstrated that $100 \%$ of CRC patients had normal MM genotype. In a study of 267 CRC patients from Spain, Pérez-Holanda et al. [22] observed a higher frequency of A1AT deficientassociated $Z$ allele in CRC cases than healthy controls. However, they found no significant difference in serum A1AT concentrations between normal (MM) and deficient (MS, MZ or SZ) genotypes.

Previous immunohistochemical studies of biopsies from gastric and CRC tumors indicated a local overexpression of A1AT by tumor cells and a higher expression of A1AT in advanced adenocarcinomas than in early carcinomas $[36$, 37]. It has been reported that A1AT expression in cells is controlled by promoter DNA methylation [30]. Therefore, we examined the methylation status of SERPINA1 gene promoter in 86 tumors and their adjacent normal tissues. SerpinA1 promoter was either fully-methylated or hemimethylated in tumor tissues (Table 3). The rate of fullymethylated gene in normal tissues was significantly higher than that in tumor tissues $(53.2 \%$ versus $8.1 \%, p<0.0001)$. The results also indicated that SERPINA1 was more frequently methylated in well-differentiated tumors $(p<0.05)$ than in other differentiation subgroups. There was no relationship between gene promoter methylation and other clinicopathological features.

Multiple mechanisms have been proposed to explain the elevated levels of serum AIAT in cancer patients, including an enhanced A1AT production by mononuclear cells, liver or tumor cells themselves [11, 37, 38]. Since transcriptionally active A1AT gene is hypomethylated and the inactive gene is hypermethylated [30], it is plausible that tumors with the hypomethylated promoter express more A1AT protein than normal tissues and tumors with the hypermethylated promoter. Our findings suggest that A1AT production by tumor cells themselves might have a role for the elevation of plasma A1AT levels in CRC patients. This viewpoint is supported by our observation of higher levels of plasma A1AT in cases with large tumor size $(\geq 5 \mathrm{~cm})$ than in those with small tumors $(<5 \mathrm{~cm})(p<0.0001)$ (Table 2). Yet more in-depth studies using larger sample sizes are necessary to validate the findings of present study. 


\section{Conclusion}

Our study indicated that A1AT concentrations and activity levels in circulation have a better sensitivity and specificity than CEA measurement for the early detection of CRC. Our findings also suggest that the increased expression of A1AT gene in primary tumor tissues because of the promoter hypomethylation might play a role in increasing plasma A1AT levels in CRC patients.

Acknowledgments This study was a part of the dissertation of Hajar Jaberie, submitted to Shiraz University of Medical Sciences in partial fulfillment of the requirements for the $\mathrm{Ph}$. D in clinical biochemistry. This work was supported by a grant (grant number 92-6699) from the Vice Chancellor for Research, Shiraz University of Medical Sciences.

\section{Compliance with Ethical Standards}

Conflict of Interest We declare that we have no conflict of interest.

\section{References}

1. Arnold M, Sierra MS, Laversanne M, Soerjomataram I, Jemal A, Bray F (2017) Global patterns and trends in colorectal cancer incidence and mortality. Gut 66:683-691

2. Dolatkhah R, Somi MH, Bonyadi MJ, Asvadi Kermani I, Farassati F, Dastgiri S (2015) Colorectal cancer in Iran: molecular epidemiology and screening strategies. J Cancer Epidemiol 2015:643020

3. Duffy MJ, van Dalen A, Haglund C, Hansson L, Holinski-Feder E, Klapdor R, Lamerz R, Peltomaki P, Sturgeon C, Topolcan O (2007) Tumour markers in colorectal cancer: European Group On Tumour Markers (EGTM) guidelines for clinical use. Eur J Cancer 43:1348-1360

4. Pakdel A, Malekzadeh M, Naghibalhossaini F (2016) The association between preoperative serum CEA concentrations and synchronous liver metastasis in colorectal cancer patients. Cancer Biomark $16: 245-252$

5. Chuang SC, Su YC, Lu CY, Hsu HT, Sun LC, Shih YL, Ker CG, Hsieh JS, Lee KT, Wang JY (2011) Risk factors for the development of metachronous liver metastasis in colorectal cancer patients after curative resection. World J Surg 35:424-429

6. Duffy MJ, Lamerz R, Haglund C, Nicolini A, Kalousová M, Holubec L, Sturgeon C (2014) Tumor markers in colorectal cancer, gastric cancer and gastrointestinal stromal cancers: European group on tumor markers 2014 guidelines update. Int J Cancer 134:2513-2522

7. Balkwill F, Mantovani A (2001) Inflammation and cancer: back to Virchow? Lancet. 357:539-545

8. Wang F, Arun P, Friedman J, Chen Z, Van Waes C (2009) Current and potential inflammation targeted therapies in head and neck cancer. Curr Opin Pharmacol 9:389-395

9. Ghuman S, Van Hemelrijck M, Garmo H, Holmberg L, Malmström H, Lambe M, Hammar N, Walldius G, Jungner I, Wulaningsih W (2017) Serum inflammatory markers and colorectal cancer risk and survival. Br J Cancer 116:1358-1365

10. Slattery ML, Wolff RK, Herrick J, Caan BJ, Samowitz W (2009) Tumor markers and rectal cancer: support for an inflammationrelated pathway. Int J Cancer 125:1698-1704

11. Kittas C, Aroni K, Kotsis L, Papadimitriou CS (1982) Distribution of lysozyme, alpha-I-antichymotrypsin and alpha-I-antitrypsin in adenocarcinomas of the stomach and large intestine. An immunohistochemical study. Virchows Arch [A] 398:139-147

12. Greene CM, McElvaney NG (2009) Proteases and antiproteases in chronic neutrophilic lung disease - relevance to drug discovery. $\mathrm{Br} \mathrm{J}$ Pharmacol 158:1048-1058

13. Shahaf G, Moser H, Ozeri E, Mizrahi M, Abecassis A, Lewis EC (2011) Alpha-1-antitrypsin gene delivery reduces inflammation, increases T-regulatory cell population size and prevents islet allograft rejection. Mol Med (Cambridge, Mass) 17:1000-1011

14. McCarthy C, Saldova R, Wormald MR, Rudd PM, McElvaney NG, Reeves EP (2014) The role and importance of glycosylation of acute phase proteins with focus on alpha- 1 antitrypsin in acute and chronic inflammatory conditions. J Proteome Res 13:3131-3143

15. El-Akawi ZJ, Al-Hindawi FK, Bashir NA (2008) Alpha-1 antitrypsin (alpha1-AT) plasma levels in lung, prostate and breast cancer patients. Neuro Endocrinol Lett 29:482-484

16. Propst T, Propst A, Dietze O, Judmaier G, Braunsteiner H, Vogel W (1994) Prevalence of hepatocellular carcinoma in alpha-1antitrypsin deficiency. J Hepatol 21:1006-1011

17. Benkmann HG, Hanssen HP, Ovenbeck R, Goedde HW (1987) Distribution of alpha-1-antitrypsin and haptoglobin phenotypes in bladder cancer patients. Hum Hered 37:290-293

18. Ganji SM, Sahebghadam-Lotfi A, Rastgar-Jazii F, Yazdanbod M, Mota A, Mohsenifar A, Kazemnejad A (2010) Alpha-1 antitrypsin deficient squamous cell carcinoma of esophagus in the Azeri population of Iran. Lab Med 41:613-618

19. Trachte AL, Suthers SE, Lerner MR, Hanas JS, Jupe ER, Sienko AE, Adesina AM, Lightfoot SA, Brackett DJ, Postier RG (2002) Increased expression of alpha-1-antitrypsin, glutathione Stransferase pi and vascular endothelial growth factor in human pancreatic adenocarcinoma. Am J Surg 184:642-647 discussion 647-8

20. Xie LQ, Zhao C, Cai SJ, Xu Y, Huang LY, Bian JS, Shen CP, Lu HJ, Yang PY (2010) Novel proteomic strategy reveal combined alphal antitrypsin and cathepsin D as biomarkers for colorectal cancer early screening. J Proteome Res 9:4701-4709

21. Kwon CH, Park HJ, Choi JH, Lee JR, Kim HK, Jo HJ, Kim HS, Oh N, Song GA, Park DY (2015) Snail and serpinA1 promote tumor progression and predict prognosis in colorectal cancer. Oncotarget 6:20312-20326

22. Pérez-Holanda S, Blanco I, Menéndez M, Rodrigo L (2014) Serum concentration of alpha-1 antitrypsin is significantly higher in colorectal cancer patients than in healthy controls. BMC Cancer 14:355

23. Yang P, Cunningham JM, Halling KC, Lesnick TG, Burgart LJ, Wiegert EM, Christensen ER, Lindor NM, Katzmann JA, Thibodeau SN (2000) Higher risk of mismatch repair-deficient colorectal cancer in alpha (1)-antitrypsin deficiency carriers and cigarette smokers. Mol Genet Metab 71:639-645

24. Lindor NM, Yang P, Evans I, Schowalter K, De Andrade M, Li J, Jeavons E, Peterson G, Gallinger S, Bapat B, Hopper J, Jass J, Jenkins M, Templeton A, Potter J, Newcomb PA, Lemarchand L, Grove J, Haile R, Baron J, Seminara D, Limburg P, Thibodeau SN (2010) Alpha-1-antitrypsin deficiency and smoking as risk factors for mismatch repair deficient colorectal cancer: a study from the colon cancer family registry. Mol Genet Metab 99:157-159

25. Peltier J, Roperch JP, Audebert S, Borg JP, Camoin (2016) Quantitative proteomic analysis exploring progression of colorectal cancer: modulation of the serpin family. J Proteome 148:139-148

26. Bujanda L, Sarasqueta C, Cosme A, Hijona E, Enríquez-Navascués JM, Placer C, Villarreal E, Herreros-Villanueva M, Giraldez MD, Gironella M, Balaguer F, Castells A (2013) Evaluation of alpha 1antitrypsin and the levels of mRNA expression of matrix metalloproteinase 7 , urokinase type plasminogen activator receptor and COX-2 for the diagnosis of colorectal cancer. PLoS One 8:e51810

27. Topic A, Juranic Z, Jelic S, Magazinovic IG (2009) Polymorphism of alpha-1-antitrypsin in hematological malignancies. Genet Mol Biol 32:716-719 
28. Yang P, Sun Z, Krowka MJ, Aubry MC, Bamlet WR, Wampfler JA, Thibodeau SN, Katzmann JA, Allen MS, Midthun DE, Marks RS, de Andrade M (2008) Alpha1-antitrypsin deficiency carriers, tobacco smoke, chronic obstructive pulmonary disease, and lung cancer risk. Arch Intern Med 168:1097-1103

29. Qiu W, Baccarelli A, Carey VJ, Boutaoui N, Bacherman H, Klanderman B, Rennard S, Agusti A, Anderson W, Lomas DA, DeMeo DL (2012) Variable DNA methylation is associated with chronic obstructive pulmonary disease and lung function. Am J Respir Crit Care Med 185:373-381

30. Barton DE, Francke U (1987) Activation of human alpha 1antitrypsin genes in rat hepatoma $\mathrm{x}$ human fibroblast hybrid cell lines is correlated with demethylation. Somat Cell Mol Genet 13: 635-644

31. Jaberie H, Naghibalhossaini F (2016) Recombinant production of native human $\alpha$-1-antitrypsin protein in the liver HepG2 cells. Biotechnol Lett 38:1683-1690

32. Sarabi MM, Naghibalhossaini F (2015) Association of DNA methyltransferases expression with global and gene-specific DNA methylation in colorectal cancer cells. Cell Biochem Funct 33:427-433

33. Laffranchi M, Elliston ELK, Gangemi F, Berardelli R, Lomas DA, Irving JA, Fra A (2019) Characterisation of a type II functionallydeficient variant of alpha-1-antitrypsin discovered in the general population. PLoS One 14:e0206955
34. Haq I, Irving JA, Saleh AD, Dron L, Regan-Mochrie GL, Motamedi-Shad N, Hurst JR, Gooptu B, Lomas DA (2016) Deficiency mutations of Alpha-1 antitrypsin. Effects on folding, function, and polymerization. Am J Respir Cell Mol Biol 54:71-80

35. Ward DG, Suggett N, Cheng Y, Wei W, Johnson H, Billingham LJ, Ismail T, Wakelam MJ, Johnson PJ, Martin A (2006) Identification of serum biomarkers for colon cancer by proteomic analysis. Br J Cancer 94:1898-1905

36. Karashima S, Kataoka H, Itoh H, Maruyama R, Koono M (1990) Prognostic significance of alpha-1-antitrypsin in early stage of colorectal carcinomas. Int J Cancer 45:244-250

37. Tahara E, Ito H, Taniyama K, Yokozaki H, Hata J (1984) Alpha 1antitrypsin, alpha 1-antichymotrypsin, and alpha 2-macroglobulin in human gastric carcinomas: a retrospective immunohistochemical study. Hum Pathol 15:957-964

38. Weissmann G, Zurier RB, Hoffstein S (1970) Leucocytic proteases and the immunological release of lysosomal enzymes. Am J Pathol 68:539-560

Publisher's Note Springer Nature remains neutral with regard to jurisdictional claims in published maps and institutional affiliations. 